Jurnal Mahasiswa BK An-Nur : Berbeda, Bermakna, Mulia

Volume 7 Nomer 3 Tahun 2021

Tersedia Online: https://ojs.uniska-bjm.ac.id/index.php/AN-NUR

p-ISSN. 2460-9722 | e-ISSN. 2622-8297

\title{
PENGEMBANGAN PROGRAM BIMBINGAN KARIER UNTUK MENINGKATKAN ADAPTABILITAS KARIER SISWA JURUSAN IPA SMA NEGERI 7 BEKASI
}

\author{
Siti Farida Basyarah ${ }^{1}$, Happy Karlina Marjo $^{2}$, Herdi $^{3}$ \\ ${ }^{123}$ Fakultas Ilmu Pendidikan, Universitas Negeri Jakarta, \\ E-mail: faridabasyarah@gmail.com
}

\begin{abstract}
ABSTRAK
Tujuan umum penelitian ini adalah menghasilkan program karier untuk meningkatkan adaptabilitas karier siswa jurusan IPA SMA Negeri 7 Bekasi. Secara khusus, tujuan penelitian adalah memperoleh data empirik sebagai berikut ini: (1) Pengembangan program bimbingan karier untuk meningkatkan adaptabilitas karier siswa jurusan IPA SMA Negeri 7 Bekasi. (2) Kelayakan program bimbingan karier untuk meningkatkan adaptabilitas karier siswa jurusan IPA SMA Negeri 7 Bekasi. Dalam penelitian ini menggunakan Design Based Research model Amiel \& Reeves. Subjek dalam penelitian ini adalah peserta didik Kelas XII IPA SMA Negeri 7 Bekasi. Pengumpulan data menggunakan kuesioner, wawancara, dan observasi. Hasil penelitian ini adalah hasil identifikasi masalah dengan menyebarkan angket adaptabilitas karier diperoleh adaptabilitas karier siswa kelas XII Jurusan IPA dengan mean measure sebesar 2.88, skor bergerak dari kategori rendah sampai dengan kategori tinggi dengan skor minimum sebesar 1.08, skor maksimal sebesar 4.88, dan standar deviasi sebesar 1.08 . Berdasarkan hasil analisis, secara umum profil adaptabilitas karier siswa berada di rata-rata. Pengembangan program bimbingan karier untuk meningkatkan adaptabilitas karier siswa kelas XII IPA SMAN 7 Bekasi telah melalui tahap yaitu uji ahli bimbingan karier dalam menilai kelayakan program dengan nilai 73,33\% artinya program bimbingan karier untuk meningkatkan adaptabilitas karier siswa kelas XII IPA SMAN 7 Bekasi adalah layak. Selanjutnya, hasil uji kelayakan pengguna program bimbingan karier untuk meningkatkan adaptabilitas karier siswa kelas XII IPA SMAN 7 Bekasi adalah $76,66 \%$ artinya layak. Hasil evaluasi langkah pengembangan program bimbingan karier untuk meningkatkan adaptabilitas karier siswa kelas XII IPA SMAN 7 Bekasi memiliki kategori baik karena memiliki nilai 77,14\%.
\end{abstract}

Kata kunci: Program Bimbingan Karier, Adaptabilitas Karier

\section{ABSTRACT}

The general objective of this research is to produce a career program to improve the career adaptability of students majoring in science at SMA Negeri 7 Bekasi. In particular, the research objective is to obtain empirical data as follows: (1) Development of a career guidance program to improve the career adaptability of students majoring in science at SMA Negeri 7 Bekasi. (2) The feasibility of a career guidance program to improve the career adaptability of students majoring in science at SMA Negeri 7 Bekasi. In this study using the Design Based Research model Amiel \& Reeves. The subjects in this study were students of class XII science at SMA Negeri 7 Bekasi. Collecting data using questionnaires, interviews, and observations. The results of this study are the results of problem identification by distributing career adaptability questionnaires, the career adaptability of class XII students of the Natural Sciences Department is obtained with a mean measure of 2.88, the score moves from the low category to the high category with a minimum score of 1.08, a maximum score of 4.88, and a standard deviation of 1.08. Based on the results of the analysis, in general, students' career adaptability profiles are on average. The development of a career guidance program to improve the career adaptability of class XII IPA SMAN 7 Bekasi has gone through the stages, namely the career guidance expert test in assessing the feasibility of the program with a value of $73.33 \%$, meaning that the career guidance program to improve the career adaptability of class XII IPA SMAN 7 Bekasi is feasible. . Furthermore, the results of the feasibility test for users of the career guidance program to improve the career adaptability of class XII science students at SMAN 7 Bekasi is 76.66\%, which means that it is feasible. The results of the evaluation of the steps for developing a career guidance program to improve the career adaptability of class XII science students at SMAN 7 Bekasi have a good category because they have a score of $77.14 \%$.

Keywords: Career Guidance Program, Career Adaptability

Dipublikasikan Oleh :

UPT Publikasi dan Pengelolaan Jurnal

Universitas Islam Kalimantan Muhammad Arsyad Al-Banjari Banjarmasin 


\section{Siti Farida Basyarah ${ }^{1}$, Happy Karlina Marjo ${ }^{2}$, Herdi $^{3}$ Jurnal Mahasiswa BK An-Nur : Berbeda, Bermakna, Mulia Volume 7 Nomer 3 Tahun 2021 \\ Tersedia Online: https://ojs.uniska-bjm.ac.id/index.php/AN-NUR p-ISSN. 2460-9722 | e-ISSN. 2622-8297}

\section{PENDAHULUAN}

Banyak permasalahan yang timbul ketika anak-anak menginjak masa remaja yang disebabkan oleh perubahan fisik, masalah sosial, akademik, serta karier. Masalah fisik biasanya timbul karena hasrat seksual yang ingin terpuaskan seiring dengan matangnya organ-organ seksual. Berikutnya, masalah sosial yang sering terjadi saat masa remaja yaitu masalah percintaan dan pertemanan. Selanjutnya, masalah bidang akademik yaitu masalah belajar yang terganggu dengan pengaruh narkoba, tawuran, tidak disiplin, dan lain-lain.

Permasalahan lain dari remaja yang tidak dapat dihindari yaitu masalah yang berhubungan dengan karier sebagai siswa. Hal ini menjadi konsekuensi logis dari masa perkembangan remaja yang dituntut untuk mempersiapkan kariernya.

Penelitian yang dilakukan Saka dkk (Kelly, 2015) menyatakan remaja yang tidak memiliki pilihan karier yang jelas cenderung memiliki gangguan emosi dan kepribadian seperti pesimistis, gangguan kecemasan (anxiety), dan konsep diri negatif serta self esteem yang rendah. Berikutnya, Creed \& Fallon (Creed et al., 2009) menjelaskan 166 siswa SMA di Australia menunjukkan bahwa kematangan karier berkaitan dengan kematangan konsep diri secara umum. Hasil penelitian lain yang dilaksanakan oleh Esters dan Bowen (Purwanta, 2012) terhadap siswa sekolah pertanian menemukan bahwa orangtua (ibu dan ayah) merupakan faktor pertama yang berpengaruh terhadap pilihan karier anak mereka. Adiputra (Adiputra \& Saputra, 2015) juga melakukan penelitan pada siswa di SMA Yasmida Ambarawa yang terindikasi memiliki pemahaman yang rendah pada perencanaan pemilihan karier.

Dari hasil studi pendahuluan diketahui bahwa siswa kelas XII Jurusan IPA di SMA Negeri 7 bekasi belum mempersiapkan untuk beradaptasi dengan lingkungan baru Pendidikan dan dunia kerja setelah lulus dari SMA.

Savickas (Savickas, 1997) mendefinisikan adaptabilitas karier sebagai kesiapan untuk mengatasi tugas yang terprediksi untuk mempersiapkan dan turut berperan dalam pekerjaan, pendidikan, serta mampu mengatasi situasi yang tidak terduga yang mungkin muncul sebagai perubahan dalam pekerjaan, kondisi kerja dan pendidikan. Lebih lanjut Rottinghaus, Day, \& Borgen (Creed et al., 2009) mendefinisikannya sebagai kecenderungan yang mempengaruhi cara seseorang dalam melihat kapasitasnya untuk merencanakan dan menyesuaikan diri dengan rencana perubahan- perubahan dalam kariernya, terutama dalam menghadapi hal- hal yang tidak terprediksi.

Savickas mengemukakan terdapat empat dimensi sumber adaptabilitas karier yang disebut adapt-abilities; kepedulian (concern) yaitu perhatian mengenai masa depan individu dan membantu individu untuk melihat ke depan dan mempersiapkan apa yang akan terjadi selanjutnya, pengendalian (control) memungkinkan individu bertanggung jawab untuk membentuk diri dan lingkungan mereka agar dapat memenuhi apa yang akan terjadi selanjutnya dengan menggunakan disiplin diri, usaha, dan ketekunan, keingintahuan (curiosity) timbul karena beberapa kemungkinan dan alternatif skenario yang dapat terjadi pada diri sendiri, terbentuk dengan cara eksplorasi diri saat rasa ingin tahu mendorong seseorang untuk memikirkan diri sendiri dalam berbagai situasi dan peran, Pengalaman eksplorasi dan aktivitas pencarian informasi ini menghasilkan aspirasi dan membangun keyakinan bahwa orang tersebut dapat mengaktualisasikan pilihan untuk menerapkan desain hidupnya yang kemudian akan menghasilkan kepercayaan diri (confidence) (Savickas \& Porfeli, 2012).

Penelitian yang dilakukan oleh Sisca terkait dimensi adaptabilitas karier remaja menunjukkan bahwa dimensi kepedulian (concern) merupakan aspek yang paling tinggi dari semua aspek dimensi pada adaptabilitas karier. Kesimpulan yang dapat ditarik dari penelitian ini adalah Jika dilihat dari dimensi kepedulian, seseorang akan memiliki kesadaran, terlibat akan hal yang berkaitan dengan karier yang diminatinya, dan mempersiapkan segala sesuatu yang berkaitan dengan karier (Sisca \& William Gunawan, 2015).

Masalah di atas adalah masalah yang umum dialami oleh siswa SMA karena siswa SMA tidak disiapkan untuk bekerja setelah lulus, tetapi mereka dipersiapkan untuk melanjutkan ke Perguruan Tinggi. Berbeda dengan siswa SMK yang dipersiapkan untuk bekerja sesuai dengan kompetensi yang dimilikinya. Tetapi, bukan menjadi alasan bagi guru BK untuk tidak mempersiapkan bimbingan karier terhadap siswa SMA yang difokuskan kepada pengenalan minat dan bakat, persiapan dalam memilih pekerjaan untuk masa depannya. Pada pendidikan SMA, bimbingan karier merupakan salah satu jenis bidang bimbingan yang dapat memberikan informasi kepada para siswa mengenai minat karier yang diinginkan. Secara umum bimbingan karier disekolah adalah untuk membantu siswa memiliki keterampilan dalam mengambil keputusan mengenai karier dimasa depan (Kasim, 2001).

Dipublikasikan Oleh : 


\section{Siti Farida Basyarah ${ }^{1}$, Happy Karlina Marjo ${ }^{2}$, Herdi $^{3}$ \\ Jurnal Mahasiswa BK An-Nur : Berbeda, Bermakna, Mulia \\ Volume 7 Nomer 3 Tahun 2021 \\ Tersedia Online: https://ojs.uniska-bjm.ac.id/index.php/AN-NUR \\ p-ISSN. 2460-9722 | e-ISSN. 2622-8297}

Hasil penelitian yang dilakukan oleh Darwin, menyimpulkan bahwa masih banyak siswa SMA masih belum mengetahui tentang jenis-jenis pelayanan dalam bimbingan dan konseling. Dalam hal ini seharusnya siswa sudah mengetahui jenis layanan bimbingan dan konseling khususnya di bidang karier, karena bimbingan karier sangat berpengaruh bagi siswa, terutama pada siswa SMA yang seharusnya sudah mengetahui deskripsi tentang karier dan pekerjaan yang tepat untuk diri mereka sendiri (Darwin et al., 2020).

Program bimbingan karier di SMA adalah program yang berguna untuk membantu siswa untuk dapat mempersiapkan karier yang tepat dan diharapkan berkembang maksimal dengan kariernya tersebut. Hal tersebut sejalan dengan teori Super yang menyatakan bahwa karier adalah sebuah pilihan yang sudah melalui tahapan-tahapan proses kehidupan individu dalam mencari karier yang sesuai dengan dirinya.

Penelitian dari Rifaedah, menyatakan bahwa program bimbingan karier dirancang untuk membantu siswa memantapkan pilihan kariernya. Oleh karena itu, diharapkan kepada Guru BK menggunakan program ini guna memberikan layanan bimbingan kepada siswa tengah mengalami kebingungan, bimbang, atau ragu-ragu dalam menentukan pilihan kariernya. Serangkaian dari kegiatan tersebut dapat dilaksanakan secara individual maupun kelompok tergantung pada pertimbangan waktu, jumlah siswa, atau faktor pendukung lainnya (Rifaedah, 2014).

Berdasarkan uraian di atas, upaya yang ditempuh dalam membantu mempersiapkan siswa untuk beradaptasi dengan lingkungan baru pendidikan dan dunia kerja adalah dengan menyusun suatu program layanan bimbingan karier yang layak untuk meningkatkan adaptabilitas karier siswa jurusan IPA SMA Negeri 7 Bekasi.

\section{METODE}

Dalam penyusunan pengembangan program bimbingan karier ini mengacu kepada metode Design Based Research (DBR). Plomp (Clark, 2013) menjelaskan bahwa DBR merupakan sistematis pendidikan dan instruksional proses desain yang di dalamnya memiliki proses kegiatan analisis, desain, evaluasi, dan revisi sehingga mendapatkan hasil yang memuaskan.

Tel Amiel dan Thomas C. Reeves dalam jurnal yang berjudul "Design-Based Research and Educational Technology: Rethinking Technology and the Research Agenda" (Amiel \& Reeves, 2008), mereka menjelaskan tahap-tahap pada metode DBR, yaitu sebagai berikut:

\section{Bagan1: Kerangka Design Based Research}

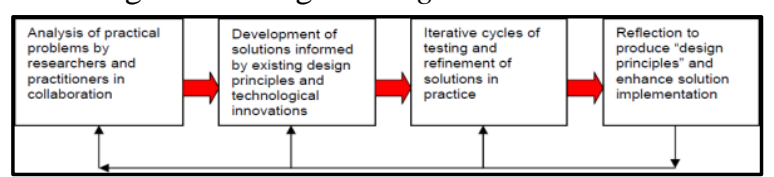

(Amiel \& Reeves, 2008)

Berdasarkan desain penelitian di atas, maka dapat dijelaskan tahapan penelitian sebagai berikut.

1. Tahap Pertama : Identifikasi dan analisis masalah

Diawali dengan pelaksanaan asesmen kegiatan dengan penyebaran instrumen Career AdaptAbilities Scale (CAAS) di kelas XII jurusan IPA. Tahap ini bertujuan supaya Guru BK dapat mengidentifikasi profil adaptabilitas karier siwa jurusan IPA sebelum dilakukannya layanan bimbingan karier untuk meningkatkan adaptabilitas karier.

2. Tahap Kedua : Perancangan program

Pada tahap penelitian ini merupakan tahapan dimana peneliti merancang seluruh jalannya proses penelitian. Mulai dari penyusunan program bimbingan karier, serta membuat RPL BK untuk meningkatkan adaptabilitas karier berdasarkan need assesment. Sebelum program ini dilaksanakan, terlebih dahulu program bimbingan karier di validasi oleh dosen ahli dalam bidangnya. Hasil validasi dapat dilihat dari catatan yang diberikan kemudian dilakukan perbaikan. 3. Tahap Ketiga : Siklus berulang

Pada tahap ini, peneliti melakukan validasi uji pengguna kepada Guru BK di SMA Negeri 7 Bekasi sebelum dilaksanakannya layanan bimbingan karier. Pelaksanaan layanan bimbingan karier dilakukan sebanyak empat kali pertemuan dengan melakukan layanan bimbingan klasikal dan kelompok dengan fungsi layanannya adalah pemahaman dan pengembangan.

Topik layanan RPL BK yang diberikan kepada siswa berdasarkan pengembangan dari empat dimensi adaptabilitas karier, yaitu concern, control, coriousty, dan confidence. Pertemuan pertama yaitu layanan bimbingan klasikal, dengan memberikan layanan informasi mengenai perencanaan karier di masa depan. Pertemuan ke dua masih dengan layanan bimbingan klasikal, dengan memberikan gambaran kepada siswa bagaimana memilih program studi/jurusan idaman. Pertemuan ke tiga, siswa mencari tahu dan mengumpulkan informasi bagaimana belajar sukses dari tokoh yang sudah berhasil. Dan di pertemuan terakhir bagi siswa yang ingin belajar pengalaman baru menjadi seorang youtuber akan dilaksanakan layanan bimbingan kelompok.

Dipublikasikan Oleh :

UPT Publikasi dan Pengelolaan Jurnal

Universitas Islam Kalimantan Muhammad Arsyad Al-Banjari Banjarmasin 
Siti Farida Basyarah ${ }^{1}$, Happy Karlina Marjo ${ }^{2}$, Herdi $^{3}$ Jurnal Mahasiswa BK An-Nur : Berbeda, Bermakna, Mulia

Volume 7 Nomer 3 Tahun 2021

Tersedia Online: https://ojs.uniska-bjm.ac.id/index.php/AN-NUR

p-ISSN. 2460-9722 | e-ISSN. 2622-8297

\section{Tahap Empat : Refleksi}

Setelah melaksanakan layanan bimbingan karier, peneliti berkolaborasi dengan Guru BK mengevaluasi apakah program bimbingan karier untuk meningkatkan adapatabilitas karier ini efektif atau tidak. Evaluasi ini dilakukan dengan berdiskusi untuk mengetahui apa kekuarangan dan kelebihan di setiap materi layanan yang sudah diberikan, bagaimana respon siswa pada saat dan sesudah diberikan layanan bimbingan karier, serta masukan dari Guru BK untuk meningkatkan kualitas program bimbingan karier untuk meningkatkan adaptabilitas karier.

\section{HASIL DAN PEMBAHASAN}

Peneliti akan membahas langkah-langkah dalam penelitian yang digunakan yaitu Design Based Research model Reeves berdasarkan data yang telah diperoleh, yaitu :

\section{A. Identifikasi Dan Analisis Masalah}

Profil umum adaptabilitas karier siswa kelas XII Jurusan IPA dengan mean measure sebesar 2.88, skor bergerak dari kategori rendah sampai dengan kategori tinggi dengan skor minimum sebesar 1.08 dengan standar deviasi sebesar 1.08. Berdasarkan hasil analisis, secara umum profil adaptabilitas karier siswa berada di rata-rata yang artinya siswa sudah dalam proses atau usaha mempersiapkan dirinya untuk menghadapi perubahan peran dan ikut berpartisipasi pada masa transisi yang akan dijalani.

Tabel 1: Profil Adaptabilitas Karier

\begin{tabular}{|l|c|c|}
\hline \multicolumn{1}{|c|}{ Deskripsi } & $\begin{array}{c}\text { Rata } \\
\text { Skor }\end{array}$ & $\begin{array}{c}\text { Standar } \\
\text { Deviasi }\end{array}$ \\
\hline Adaptabilitas & 2.88 & 1.08 \\
Karier Siswa \\
$\begin{array}{l}\text { Jurusan IPA SMA } \\
\text { Negeri 7 Bekasi }\end{array}$ & & \\
\hline
\end{tabular}

Tabel 2: Profil Adaptabilitas Karier Berdasarkan Dimensi Adaptabilitas Karier

\begin{tabular}{|c|c|c|}
\hline $\begin{array}{c}\text { Dimensi } \\
\text { Adaptabilitas } \\
\text { Karier }\end{array}$ & $\begin{array}{c}\text { Rata } \\
\text { Skor }\end{array}$ & $\begin{array}{c}\text { Standar } \\
\text { Deviasi }\end{array}$ \\
\hline Concern & 3.07 & 1.20 \\
\hline Control & 2.91 & 1.14 \\
\hline Coriousity & 2.69 & 1.03 \\
\hline Confidence & 2.86 & 1.09 \\
\hline
\end{tabular}

Berdasarkan hasil analisis, dimensi concern (kepedulian) memiliki nilai rerata lebih tinggi dibandingkan dimensi lainnya. Data tersebut menunjukkan bahwa siswa jurusan IPA lebih peduli dalam mempersiapkan tindakan/ keputusan dalam pemilihan kariernya. Sedangkan dimensi coriousity (rasa ingin tahu) memiliki nilai rerata lebih rendah dibandingkan dimensi lainnya. Data tersebut menunjukkan bahwa siswa jurusan IPA masih rendah dalam mencari tahu / informasi mengenai peluangpeluang-peluang karier di masa depan.

\section{B. Perancangan Program}

1. Analisis Hasil Uji Kelayakan

Penilaian ahli dilakukan untuk mengetahui apakah pengembangan program yang peneliti buat sudah layak atau belum untuk digunakan di sekolah, penilaian ahli atau uji ahli dilakukan oleh para ahli dalam perancangan model atau program untuk mendapatkan masukan, tanggapan, kritik, dan saran untuk perbaikan program yang sedang di kembangkan.

Uji ahli dalam penelitian ini dilakukan pada bulan Agustus 2021 oleh satu orang ahli program bimbingan karier yaitu Dr. Dede Rahmat Hidayat, M.Psi, beliau adalah dosen pengajar di program studi Bimbingan dan Konseling Universitas Negeri Jakarta.

Tabel 3: Hasil Validasi Dosen Ahli untuk Program Bimbingan Karier untuk Meningkatkan Adaptabilitas Karier

\begin{tabular}{|c|c|c|c|}
\hline No & $\begin{array}{c}\text { Komponen } \\
\text { Program }\end{array}$ & Skor & Keterangan \\
\hline $\mathrm{A}$ & Rasional & 3 & Direvisi \\
\hline $\mathrm{B}$ & Visi dan Misi & 4 & $\begin{array}{l}\text { Tidak Perlu } \\
\text { Direvisi }\end{array}$ \\
\hline $\mathrm{C}$ & Tujuan Program & 4 & $\begin{array}{l}\text { Tidak Perlu } \\
\text { Direvisi }\end{array}$ \\
\hline $\mathrm{D}$ & Deskripsi Kebutuhan & 4 & $\begin{array}{l}\text { Tidak Perlu } \\
\text { Direvisi }\end{array}$ \\
\hline $\mathrm{E}$ & $\begin{array}{l}\text { Melakukan Need } \\
\text { Asesmen }\end{array}$ & 3 & Direvisi \\
\hline $\mathrm{F}$ & Komponen Program & 4 & $\begin{array}{l}\text { Tidak Perlu } \\
\text { Direvisi }\end{array}$ \\
\hline $\mathrm{G}$ & $\begin{array}{l}\text { Target \& Sasaran } \\
\text { Program }\end{array}$ & 4 & $\begin{array}{l}\text { Tidak Perlu } \\
\text { Direvisi }\end{array}$ \\
\hline $\mathrm{H}$ & Rencana Operasional & 4 & $\begin{array}{l}\text { Tidak Perlu } \\
\text { Direvisi }\end{array}$ \\
\hline I & $\begin{array}{l}\text { Tema / Topik } \\
\text { Layanan }\end{array}$ & 4 & $\begin{array}{l}\text { Tidak Perlu } \\
\text { Direvisi }\end{array}$ \\
\hline $\mathbf{J}$ & Pengembangan RPL & 4 & $\begin{array}{l}\text { Tidak Perlu } \\
\text { Direvisi }\end{array}$ \\
\hline $\mathrm{K}$ & Evaluasi & 3 & Direvisi \\
\hline $\mathrm{L}$ & Tindak Lanjut & 3 & Direvisi \\
\hline
\end{tabular}

Berdasarkan hasil uji kelayakan di atas, maka nilai persentase nya adalah $73.33 \%$, maka program program pengembangan karier untuk meningkatkan adaptabilitas karier siswa di kelas XII IPA SMAN 7 Bekasi dinyatakan layak. 
Siti Farida Basyarah ${ }^{1}$, Happy Karlina Marjo ${ }^{2}$, Herdi $^{3}$ Jurnal Mahasiswa BK An-Nur : Berbeda, Bermakna, Mulia

Volume 7 Nomer 3 Tahun 2021

Tersedia Online: https://ojs.uniska-bjm.ac.id/index.php/AN-NUR

p-ISSN. 2460-9722 | e-ISSN. 2622-8297

2. Analisis Hasil Uji Pengguna Program

Uji pengguna dilakukan oleh satu Guru BK di SMA Negeri 7 Bekasi yang memang akan melaksanakan program bimbingan karier, yaitu Marwati S.Psi. Penilaian pengguna program bimbingan karier dilaksanakan di bulan Agustus 2021. Untuk menentukan kelayakan program menggunakan instrumen yang dikembangkan oleh peneliti sebelumnya, komponen yang di nilai yaitu:

Tabel 4: Hasil Validasi Uji Pengguna untuk Program Bimbingan Karier untuk Meningkatkan Adaptabilitas

\section{Karier}

\begin{tabular}{|c|l|c|l|}
\hline No & \multicolumn{1}{|c|}{$\begin{array}{c}\text { Komponen } \\
\text { Program }\end{array}$} & Skor & Keterangan \\
\hline A & Rasional & 4 & $\begin{array}{l}\text { Tidak Perlu } \\
\text { Direvisi }\end{array}$ \\
\hline B & Visi dan Misi & 4 & $\begin{array}{l}\text { Tidak Perlu } \\
\text { Direvisi }\end{array}$ \\
\hline C & Tujuan Program & 4 & $\begin{array}{l}\text { Tidak Perlu } \\
\text { Direvisi }\end{array}$ \\
\hline D & Deskripsi Kebutuhan & 4 & $\begin{array}{l}\text { Tidak Perlu } \\
\text { Direvisi }\end{array}$ \\
\hline E & $\begin{array}{l}\text { Melakukan Need } \\
\text { Asesmen }\end{array}$ & 4 & $\begin{array}{l}\text { Tidak Perlu } \\
\text { Direvisi }\end{array}$ \\
\hline F & Komponen Program & 4 & $\begin{array}{l}\text { Tidak Perlu } \\
\text { Direvisi }\end{array}$ \\
\hline G & $\begin{array}{l}\text { Target \& Sasaran } \\
\text { Program }\end{array}$ & 4 & $\begin{array}{l}\text { Tidak Perlu } \\
\text { Direvisi }\end{array}$ \\
\hline H & Rencana Operasional & 4 & $\begin{array}{l}\text { Tidak Perlu } \\
\text { Direvisi }\end{array}$ \\
\hline I & $\begin{array}{l}\text { Tema / Topik } \\
\text { Layanan }\end{array}$ & 4 & $\begin{array}{l}\text { Tidak Perlu } \\
\text { Direvisi }\end{array}$ \\
\hline J & Pengembangan RPL & 4 & $\begin{array}{l}\text { Tidak Perlu } \\
\text { Direvisi }\end{array}$ \\
\hline K & Evaluasi & 3 & $\begin{array}{l}\text { Tidak Perlu } \\
\text { Direvisi }\end{array}$ \\
\hline L & Tindak Lanjut & $\begin{array}{l}\text { Tidak Perlu } \\
\text { Direvisi }\end{array}$ \\
\hline
\end{tabular}

Berdasarkan hasil uji kelayakan di atas, maka nilai persentase nya adalah $76.66 \%$, maka program program pengembangan karier untuk meningkatkan adaptabilitas karier siswa di kelas XII IPA SMAN 7 Bekasi dinyatakan layak.

\section{Siklus Berulang}

Pada tahap ini, peneliti melakukan layanan bimbingan karier. Pelaksanaan layanan bimbingan karier dilakukan sebanyak empat kali pertemuan dengan melakukan layanan bimbingan klasikal dan kelompok dengan fungsi layanannya adalah pemahaman dan pengembangan. Topik layanan RPL BK yang diberikan kepada siswa berdasarkan pengembangan dari empat dimensi adaptabilitas karier, yaitu concern, control, coriousty, dan confidence. Pertemuan pertama yaitu layanan bimbingan klasikal, dengan memberikan layanan informasi mengenai perencanaan karier di masa depan. Pertemuan ke dua masih dengan layanan bimbingan klasikal, dengan memberikan gambaran kepada siswa bagaimana memilih program studi/jurusan idaman. Pertemuan ke tiga, siswa mencari tahu dan mengumpulkan informasi bagaimana belajar sukses dari tokoh yang sudah berhasil. Dan di pertemuan terakhir bagi siswa yang ingin belajar pengetahuan baru menjadi seorang youtuber akan dilaksanakan layanan bimbingan kelompok.

Tabel 5: Tema Layanan Bimbingan Karier

\begin{tabular}{|l|l|l|l|l|}
\hline No & $\begin{array}{l}\text { Dimensi } \\
\text { Adaptabilit } \\
\text { as Karier }\end{array}$ & $\begin{array}{l}\text { Skor } \\
\text { Pernyataan } \\
\text { Tertinggi }\end{array}$ & $\begin{array}{l}\text { Tema } \\
\text { Topik }\end{array}$ & $\begin{array}{l}\text { Kompone } \\
\text { n Layanan }\end{array}$ \\
\hline 1 & Concern & $\begin{array}{l}\text { Memikirkan } \\
\text { masa depan } \\
\text { saya }\end{array}$ & $\begin{array}{l}\text { Perencanaa } \\
\text { n Karier di } \\
\text { masa depan }\end{array}$ & $\begin{array}{l}\text { Bimbinga } \\
\text { n Klasikal }\end{array}$ \\
\hline 2 & Control & $\begin{array}{l}\text { Bertanggun } \\
\text { g jawab atas } \\
\text { tindakan } \\
\text { yang saya } \\
\text { lakukan }\end{array}$ & $\begin{array}{l}\text { Memilih } \\
\text { program } \\
\text { studi/jurusa } \\
\text { n idamanku }\end{array}$ & $\begin{array}{l}\text { Bimbinga } \\
\text { n Klasikal }\end{array}$ \\
\hline 3 & Coriousity & $\begin{array}{l}\text { Ingin } \\
\text { mengetahui } \\
\text { peluang- } \\
\text { peluang } \\
\text { baru }\end{array}$ & $\begin{array}{l}\text { Belajar } \\
\text { Sukses dari } \\
\text { tokoh } \\
\text { inspiratif }\end{array}$ & $\begin{array}{l}\text { Bimbinga } \\
\text { n Klasikal }\end{array}$ \\
\hline 4 & Confidence & $\begin{array}{l}\text { Berusaha } \\
\text { mengerjaka } \\
\text { n sesuatu } \\
\text { dengan baik }\end{array}$ & $\begin{array}{l}\text { Belajar } \\
\text { Menjadi } \\
\text { Youtuber }\end{array}$ & $\begin{array}{l}\text { Bimbinga } \\
\text { nelompok } \\
\text { Kelomal }\end{array}$ \\
\hline
\end{tabular}

\section{Refleksi}

Setelah melaksanakan layanan bimbingan karier, peneliti berkolaborasi dengan Guru BK merefleksi apakah program bimbingan karier untuk meningkatkan adapatabilitas karier ini efektif atau tidak. Refleksi ini dilakukan dengan berdiskusi untuk mengetahui apa kekurangan dan kelebihan di setiap materi layanan yang sudah diberikan, bagaimana respon siswa pada saat (proses) dan sesudah diberikan (hasil) layanan bimbingan karier, serta masukan dari Guru BK untuk meningkatkan kualitas program bimbingan karier untuk meningkatkan adaptabilitas karier.

Efektivitas program bimbingan karier untuk meningkatkan adaptabilitas karier Siswa Jurusan IPA di SMA Negeri 7 Bekasi berdasarkan refleksi yang dilakukan oleh pelaksana layanan program dan peneliti. Pelaksanaan refleksi dilakukan dengan diskusi oleh Guru BK dan peneliti. 
Siti Farida Basyarah ${ }^{1}$, Happy Karlina Marjo ${ }^{2}$, Herdi $^{3}$

Jurnal Mahasiswa BK An-Nur : Berbeda, Bermakna, Mulia

Volume 7 Nomer 3 Tahun 2021

Tersedia Online: https://ojs.uniska-bjm.ac.id/index.php/AN-NUR

p-ISSN. 2460-9722 | e-ISSN. 2622-8297

Pembahasan diskusi dalam refleksi ini adalah untuk mengetahui apa saja kekurangan dan kelebihan di setiap materi layanan yang sudah diberikan, bagaimana respon siswa pada saat dan sesudah diberikan layanan bimbingan karier, serta masukan dari Guru BK untuk meningkatkan kualitas program bimbingan karier untuk meningkatkan adaptabilitas karier. Untuk pembahasan pertama mengenai kekurangan dan kelebihan pada saat pelaksanaan layanan bimbingan, untuk kekurangan nya adalah pelaksanaan layanan bimbingan klasikal dilakukan secara daring dengan waktu yang lebih sedikit, ada kendala pada saat siswa masuk telat keruangan zoom karena belum selesai dimata pelajaran sebelumnya sehingga ada beberapa Langkah kegiatan Guru BK di lewati tapi tidak mengurangi esensi dari materi layanan yang diberikan. Kelebihan dalam pelaksanaan program bimbingan ini menurut pembahasan Guru BK nya adalah sebagai berikut.

1. Media persentasi yang menarik sehingga siswa dapat menyimak dengan baik.

2. Materi layanan nya memang sesuai dengan kebutuhan siswa, apalagi sebelumnya peneliti sudah membahas dengan Guru BK mengenai adaptabilitas karier.

3. Adanya lembar kerja di setiap materi layanan sehingga memudahkan Guru BK mengarahkan siswa dalam mencapai tujuan layanan

4. Dengan adanya lembar kerja juga di setiap materi layanan memudahkan siswa untuk memahami tujuan layanan dan mereka antusias mengerjakan lembar kerja tersebut.

Pembahasan kedua mengenai refleksi respon siswa pada saat dan sesudah diberikan layanan bimbingan karier. Tidak semua siswa menyalakan kamera di zoom pada saat pemberian layanan, alasannya karena takut kuota internet cepat habis sehingga untuk melakukan observasi selama proses kegiatan tidak dapat dilakukan kepada semua siswa. Antusias siswa dapat sangat terlihat pada saat layanan bimbingan kelompok, pada saat kegiatan tersebut siswa berperan aktif dalam mengikuti kegiatan karena di bimbingan kelompok mereka seperti mengikuti workshop/pelatihan kerja.

Saran atau masukan yang diberikan oleh Guru BK setelah melaksanakan program bimbingan karier ini adalah penyusunan program bimbingan karier ini sudah baik dan memang dapat mempersiapkan siswa dalam menghadapi perubahan peran karier ke depannya. Tetapi karena permasalahan karier yang dialami siswa khususnya SMA itu memiliki indikator yang banyak, seharusnya MGBK pusat atau kota memiliki pedoman baku yang khusus untuk penyusunan program bimbingan karier sehingga memudahkan guru BK yang di tingkat SMA/SMK dapat membantu mengentaskan permasalahan karier siswa.

\section{E. Evaluasi}

Peneliti telah melaksanakan evaluasi terhadap keseluruhan tahapan penelitian pengembangan program bimbingan karier untuk meningkatkan adaptabilitas karier siswa jurusan IPA SMA Negeri 7 Bekasi.

Tabel 6: Hasil Evaluasi

\begin{tabular}{|c|c|c|c|}
\hline No & Komponen Program & Skor & Keterangan \\
\hline \multicolumn{4}{|c|}{ A. Identifikasi Masalah } \\
\hline 1 & Penyebaran angket & 4 & $\begin{array}{l}\text { Tdk Perlu } \\
\text { Direvisi }\end{array}$ \\
\hline 2 & $\begin{array}{l}\text { Penghitungan Analisis } \\
\text { Angket }\end{array}$ & 4 & $\begin{array}{l}\text { Tdk Perlu } \\
\text { Direvisi }\end{array}$ \\
\hline 3 & $\begin{array}{lr}\text { Membuat } & \text { laporan } \\
\text { hasil analisis } & \\
\text { penyebaran angket }\end{array}$ & 4 & $\begin{array}{l}\text { Tdk Perlu } \\
\text { Direvisi }\end{array}$ \\
\hline 4 & $\begin{array}{l}\text { Hasil analisis } \\
\text { kebutuhan }\end{array}$ & 4 & $\begin{array}{l}\text { Tdk Perlu } \\
\text { Direvisi }\end{array}$ \\
\hline \multicolumn{4}{|c|}{ B. Perancangan Program } \\
\hline 1 & $\begin{array}{l}\text { Menyusun Program } \\
\text { Bimbingan Karier }\end{array}$ & 3 & $\begin{array}{l}\text { Tdk Perlu } \\
\text { Direvisi }\end{array}$ \\
\hline 2 & $\begin{array}{l}\text { Pengujian Kelayakan } \\
\text { Program Oleh Ahli }\end{array}$ & 4 & $\begin{array}{l}\text { Tdk Perlu } \\
\text { Direvisi }\end{array}$ \\
\hline 3 & $\begin{array}{lr}\text { Pengujian } & \text { Uji } \\
\text { Pengguna } & \text { Program } \\
\text { oleh guru BK } & \\
\end{array}$ & 4 & $\begin{array}{l}\text { Tdk Perlu } \\
\text { Direvisi }\end{array}$ \\
\hline 4 & $\begin{array}{l}\text { Tahap revisi program } \\
\text { bimbingan karier }\end{array}$ & 3 & $\begin{array}{l}\text { Tdk Perlu } \\
\text { Direvisi }\end{array}$ \\
\hline \multicolumn{4}{|c|}{ C. Siklus Berulang } \\
\hline 1 & \begin{tabular}{|lr} 
Rencana & Operasional \\
Layanan & Bimbingan \\
Karier & \\
\end{tabular} & 4 & $\begin{array}{l}\text { Tdk Perlu } \\
\text { Direvisi }\end{array}$ \\
\hline 2 & Tema/Topik Layanan & 4 & $\begin{array}{l}\text { Tdk Perlu } \\
\text { Direvisi }\end{array}$ \\
\hline 3 & $\begin{array}{l}\text { Pengembangan } \\
\text { Rencana Pelaksanaan } \\
\text { Layanan }\end{array}$ & 4 & $\begin{array}{l}\text { Tdk Perlu } \\
\text { Direvisi }\end{array}$ \\
\hline 4 & \begin{tabular}{|l|} 
Pelaksanaan \\
Operasional Layanan \\
Bimbingan Karier \\
\end{tabular} & 4 & $\begin{array}{l}\text { Tdk Perlu } \\
\text { Direvisi }\end{array}$ \\
\hline \multicolumn{4}{|c|}{ D. Refleksi } \\
\hline 1 & $\begin{array}{l}\text { Diskusi antara peneliti } \\
\text { dengan guru BK } \\
\text { mengenai kelebihan } \\
\text { dan kekurangan } \\
\text { program bimbingan } \\
\text { karier }\end{array}$ & 4 & $\begin{array}{l}\text { Tdk Perlu } \\
\text { Direvisi }\end{array}$ \\
\hline
\end{tabular}


Siti Farida Basyarah ${ }^{1}$, Happy Karlina Marjo ${ }^{2}$, Herdi $^{3}$ Jurnal Mahasiswa BK An-Nur : Berbeda, Bermakna, Mulia

Volume 7 Nomer 3 Tahun 2021

Tersedia Online: https://ojs.uniska-bjm.ac.id/index.php/AN-NUR p-ISSN. 2460-9722 | e-ISSN. 2622-8297

\begin{tabular}{|l|l|l|l|}
\hline No & Komponen Program & Skor & Keterangan \\
\hline 2 & Hasil Refleksi & 4 & $\begin{array}{l}\text { Tdk Perlu } \\
\text { Direvisi }\end{array}$ \\
\hline
\end{tabular}

Hasil evaluasi langkah pengembangan program bimbingan karier untuk meningkatkan adaptabilitas karier siswa kelas XII IPA SMAN 7 Bekasi memiliki kategori baik karena memiliki nilai 77,14\%.

\section{PENUTUP}

Hasil penelitian serta pembahasan yang telah diuraikan menghasilkan sejumlah kesimpulan sebagai berikut.

Penelitian ini dilakukan untuk mengembangkan program bimbingan karier untuk meningkatkan adaptabilitas karier siswa kelas XII IPA SMAN 7 Bekasi. Penelitian ini diawali dengan identifikasi masalah dengan menyebarkan angket adaptabilitas karier siswa, perencanaan pembuatan program bimbingan karier, siklus berulang, dan refleksi. Selanjutnya, tahapan terakhir adalah evaluasi.

Berdasarkan hasil identifikasi masalah dengan menyebarkan angket adaptabilitas karier diperoleh adaptabilitas karier siswa kelas XII Jurusan IPA dengan mean measure sebesar 2.88, skor bergerak dari kategori rendah sampai dengan kategori tinggi dengan skor minimum sebesar 1.08, skor maksimal sebesar 4.88, dan standar deviasi sebesar 1.08. Berdasarkan hasil analisis, secara umum profil adaptabilitas karier siswa berada di rata-rata.

Penelitian ini menggunakan metode penelitian Design Based Research. Penelitian ini berfokus pada pengembangan program bimbingan karier dalam meningkatkan adaptabilitas karier siswa pada dimensi concern, control, curiosity, dan confidence.

Pengembangan program bimbingan karier untuk meningkatkan adaptabilitas karier siswa kelas XII IPA SMAN 7 Bekasi telah melalui tahap yaitu uji ahli bimbingan karier dalam menilai kelayakan program dengan nilai $73,33 \%$ artinya program bimbingan karier untuk meningkatkan adaptabilitas karier siswa kelas XII IPA SMAN 7 Bekasi adalah layak. Selanjutnya, hasil uji kelayakan pengguna program bimbingan karier untuk meningkatkan adaptabilitas karier siswa kelas XII IPA SMAN 7 Bekasi adalah 76,66 \% artinya layak.

Hasil evaluasi langkah pengembangan program bimbingan karier untuk meningkatkan adaptabilitas karier siswa kelas XII IPA SMAN 7 Bekasi memiliki kategori baik karena memiliki nilai $77,14 \%$.

Adapun saran yang dapat diberikan untuk penelitian selanjutnya adalah sebagai berikut:
1. Perlu adanya penelitian lanjutan mengenai program bimbingan karier untuk meningkatkan adaptabilitas dengan melibatkan komponen program yang lain seperti layanan responsif dan layanan perencanaan individual.

2. Pada pengembangan program layanan yang paling banyak di butuhkan dan merangkul banyak siswa adalah layanan dasar, oleh karena itu perlu adanya jadwal terstruktur di sekolah untuk guru BK agar tujuan dari layanan BK karier ini lebih efektif dan tepat sasaran.

\section{REFERENSI}

Adiputra, S., \& Saputra, W. N. E. (2015). Teori Dasar Konseling. Aura Publishing.

Amiel, T., \& Reeves, T. C. (2008). Design-based research and educational technology: Rethinking technology and the research agenda. Educational Technology and Society, 11(4), 2940.

Clark, S. K. (2013). Reflection: Research by design: Design-based research and the higher degree research student. Journal of Learning Design, 8(3). https://doi.org/10.5204/jld.v8i3.257

Creed, P. A., Fallon, T., \& Hood, M. (2009). The relationship between career adaptability, person and situation variables, and career concerns in young adults. Journal of Vocational Behavior, $74(2)$, 219-229. https://doi.org/10.1016/j.jvb.2008.12.004

Darwin, M. R., Farozin, M., \& Retnawati, H. (2020). What Career Guidance and Counseling Services Are Needed by Senior High School Students? JPI (Jurnal Pendidikan Indonesia), 9(4), 608. https://doi.org/10.23887/jpiundiksha.v9i4.26281

Kasim, A. (2001). Bimbingan konseling di sekolah dan perguruan tinggi. Bimbingan Konseling Universitas Negeri Jakarta.

Kelly, K. R. (2015). Aspects of Career-DecisionMaking. 403-424.

Purwanta, E. (2012). Modifikasi Perilaku Alternatif Penanganan Anak Berkebutuhan Khusus. Pustaka Pelajar.

Rifaedah, E. (2014). Program Bimbingan Karier Untuk Memantapkan Pilihan Karier Peserta Didik. Universitas Pendidikan Indonesia.

Savickas, M. L. (1997). Career adaptability: An integrative construct for life-span, life-space theory. Career Development Quarterly, 45(3), 247-259. https://doi.org/10.1002/j.21610045.1997.tb00469.x

Savickas, M. L., \& Porfeli, E. J. (2012). Career

Dipublikasikan Oleh :

UPT Publikasi dan Pengelolaan Jurnal

Universitas Islam Kalimantan Muhammad Arsyad Al-Banjari Banjarmasin 
Siti Farida Basyarah ${ }^{1}$, Happy Karlina Marjo ${ }^{2}$, Herdi $^{3}$ Jurnal Mahasiswa BK An-Nur : Berbeda, Bermakna, Mulia Volume 7 Nomer 3 Tahun 2021

Tersedia Online: https://ojs.uniska-bjm.ac.id/index.php/AN-NUR p-ISSN. 2460-9722 | e-ISSN. 2622-8297

Adapt-Abilities Scale: Construction, reliability, and measurement equivalence across 13 countries. Journal of Vocational Behavior, $80(3)$, 661-673. https://doi.org/10.1016/j.jvb.2012.01.011

Sisca, \& William Gunawan. (2015). Gambaran Adaptabilitas Karier Remaja. Jurnal Psikologi UIN Sultan Syarif Kasim Riau, 11(Desember), 111-119. 